\title{
Performance Dependence of (I-V) and (C-V) for Solar Cells on Environmental Conditions
}

\author{
A.M. Abdel-Maksood ${ }^{1^{\star}}$, F.A.S. Soliman ${ }^{1}$ \\ Electronics Dept., Exploration Sector, Nuclear Materials Authority, \\ P. O. Box 530, Maadi-11728, Cairo, Egypt. \\ ashrafmosleh11@gmail.com \\ Fouad.Saad.Soliman@gmail.com
}

\begin{abstract}
The present paper is a trial to shed further light on the dependence performance of mono-crystalline silicon solar cell (photovoltaic cell) on the environmental conditions. In this concern, the static (I-V) and dynamic (C-V) characteristics measurement were studied in details under the effect of illumination type, intensity and wavelength, as well temperature on the physical and electrical parameters of solar cell. The dependence of cell parameters- extracted from (I-V) characteristic curves- open-circuit voltage $\left(V_{o c}\right)$, short-circuit current $\left(I_{s c}\right)$, fillfactor (FF), conversion efficiency $(\eta)$ as well the series -and shunt-resistances $\left(R_{s}\right.$ and $\left.R_{\text {sh }}\right)$, on the intensity has been investigated for a wide illumination intensity range $1.0-70 \mathrm{~mW} / \mathrm{cm}^{2}$. It was observed that, for illumination levels higher than $10 \mathrm{klux}$, the values of $V_{o c}, R_{s h}, F F$ and efficiency were shown to be saturated. $I_{s c}$ was shown to be increased linearly, while $R_{s}$ decreased exponentially as a function of illumination level. On the other hand, considering the dynamic characteristics (C-V), a detailed study was carried out for solar cells biased on both the forward - and reverse modes at frequency range of $20 \mathrm{kHz}-140 \mathrm{kHz}$ and different illumination - levels. From which, the barrier potential $\left(\mathrm{V}_{\mathrm{bi}}\right)$ and doping (charge carrier) concentration $\left(\mathrm{N}_{\mathrm{a}}\right)$ were determined. Besides, the influence of temperature within the range from 30 up to $110{ }^{\circ} \mathrm{C}$ on both the static and dynamic characteristics was tested. From which, it is clear that Voc, maximum powers $\left(P_{\text {max }}\right), F F, \eta$ of the sample were shown to be temperature decreasing functions. Moreover, $I_{s c}$ has a feeble increasing temperature coefficient. Finally, the solar cell capacitance $(C)$ and dissipation factor $(D)$ rise with rising temperature in both bias voltage conditions, while, impedance $(Z)$, quality factor $(Q)$, and phase angle $(\varphi)$ reduce with rising temperature.
\end{abstract}

\section{Keywords}

Silicon solar cells; artificial light sources; doping density; cell parameters; doping concentration.

\section{INTRODUCTION}

Solar energy is the greatest available energy source which is able of providing most of the world's energy needs. The conversion of daylight into electrical energy using solar cells system is a valuable way of producing this alternative energy [1]. Amongst the several existing photovoltaic (PV) materials, silicon (Si) is one of the most widely used semiconductors for the fabrication of solar cells. Circa $80 \%$ to $90 \%$ of PV modules manufactured worldwide are silicon wafer-based solar cells. The cost of electricity bred from solar cells is quite high as compared to traditional sources of energy, i.e., hydroelectricity, nuclear power, thermal power, etc [2]. Crystalline Si solar cells are manufactured from thin silicon wafers. For the manufacture of mono-crystalline silicon cells, silicon is molded in a cylindrical ingot form. Thin slices with thickness of $0.2-0.3 \mathrm{~mm}$ are cut from these ingots and then formed into frequently hexagonal shapes in order to cover as much of the modules aperture area as much as possible. Mass produced mono-crystalline cells have an efficiency of $13 \%$ to $17 \%$ and are the greatest efficient cells yet to enter the PV market [3]. For example, small solar cells that generate little $\mathrm{mW}$ are used in watches, calculators, small toys, radios and portable televisions [4]. When solar cells are used for indoor applications or integrated into a building, they are usually exposed to mutable irradiance intensity. The performance of a solar cell $\left(\mathrm{V}_{\mathrm{oc}} \mathrm{I}_{\mathrm{sc}} \mathrm{FF}\right.$ and $\left.\eta\right)$ is affected by these changes. These performance parameters are indirect relationship to the cell characteristics $\left(R_{s,}\right.$ and $\left.R_{s h}\right)[5]$. 


\section{STATIC and DYNAMIC CHARACTERISTICS of a SOLAR CELL}

The static characteristics of solar cell-or PV-modules can be studied via the measurement of (I-V) characteristic curves either under illumination or in the dark. From which, the cells electrical parameters $\left(V_{o c}, I_{s c}, R_{s}, R_{s h}, F F\right.$ and $\eta$ ) could be deduced. Noting that, the $R_{s}$ is an important parameter because it decreases both the shortcircuit current and the maximum power output of the cell. It is owing to the resistance of the metal contacts, ohmic losses in the front surface of the cell, impurity concentrations, and junction depth. On the other hand, the $R_{\text {sh }}$ represents the loss due to surface leakage along the edge of the cell or due to crystal defects. Furthermore, the dynamic characteristic of the solar cells or PV modules can be derived under illumination condition from the dynamic impedance model or AC equivalent circuit [6]. Capacitance measurements are an extensively used technique for the investigation of the properties of semiconductor materials [7]. Also, the diffusion $\left(C_{D}\right)$ - and transient $\left(C_{T}\right)$ - capacitances could be determined. Noting that, $C_{T}$ is voltage - dependent, $C_{T}(V)$, while $C_{D}$ is voltage- and frequency-dependent, $C_{D}(V, \omega)[6]$. Noting that, $(C-V)$ measurements are the most commonly used technique for the determination of the built-in voltage $\left(\mathrm{V}_{\mathrm{bi}}\right)$ of the cell junction and doping densities $\left(\mathrm{N}_{\mathrm{a}}\right)$ in semiconductors [8]. Wherever, the doping density can be computed from the slope of the $\left(1 / C^{2}\right)$ versus $(V)$ plot according to the Eq. [9]:

$$
N(a)=\frac{2}{q E_{S} A^{2}\left[d\left(1 / C^{2}\right) / d V\right]}
$$

where:

$N(a)$ : doping density (charge carrier concentration) $\left(1 / \mathrm{cm}^{3}\right)$,

q: electron charge $(1.60219 \times 10-19 \mathrm{C})$

$E_{s}$ : semiconductor permittivity $\left(1.034 \times 10-12 \mathrm{~F} / \mathrm{cm}\right.$ for silicon), $A$ : area $\left(\mathrm{cm}^{2}\right)$

C: measured capacitance (F), V: applied dc-voltage (V).

Finally, the proposed paper presents a trial to shed further light on studying the static (I-V) - and dynamic (C$\mathrm{V}$ ) - characteristics of mono-crystalline Si solar cells. In this concern, different experimental and theoretical procedures were carried out under a wide spectrum of illumination light sources, as well, room temperature and elevated ones.

\section{TYPES of ILLUMINATION LIGHT SOURCES and SOLAR CELLS USED}

\subsection{Electrical Illumination Sources}

The luminous intensity of lighting systems within a building is designed or adjusted to fulfill an acceptable level for the occupants; the illumination level is commonly determined in lux [10]. So, during the present study the $(\mathrm{I}-\mathrm{V})$ and $(\mathrm{C}-\mathrm{V})$ characterization of mono-crystalline Si solar cells for indoor applications, we consider the incandescent lamp, cool white fluorescent lamp, and a typical cool LED lamp [11]. As well, we compare our results with the AM 1.5G spectrum (the outdoor standard spectrum) as reference [12]. Finally, the emission spectra of different kinds of light sources including daylight (sunlight), white flood LEDs, incandescent and fluorescent bulbs are plotted as shown in Fig. (1). 


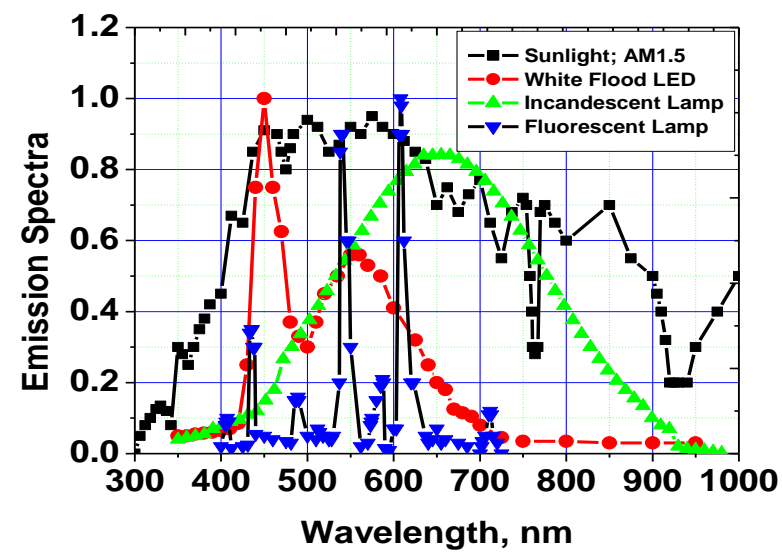

Fig. 1: Emission spectra of different kinds of light sources including daylight, white flood LED's, incandescent-and fluorescent-bulbs.

\subsection{Solar Cells Utilized}

Silicon solar cells, manufactured by Sargent-Welch, Inc., USA were used. The samples are standard n/p type with its negative terminal soldered on the light-sensitive side of the cell, while the positive terminals soldered on the back (Fig. 2). The cells are rectangular with $2.0 \mathrm{~cm} \times 1.0 \mathrm{~cm}$, in dimensions, $\mathrm{I}_{\mathrm{sc}}: 36 \mathrm{~mA}, \mathrm{~V}_{\mathrm{oc}}: 0.45 \mathrm{Volt}$, and $P_{\max }: 16 \mathrm{~mW}$.

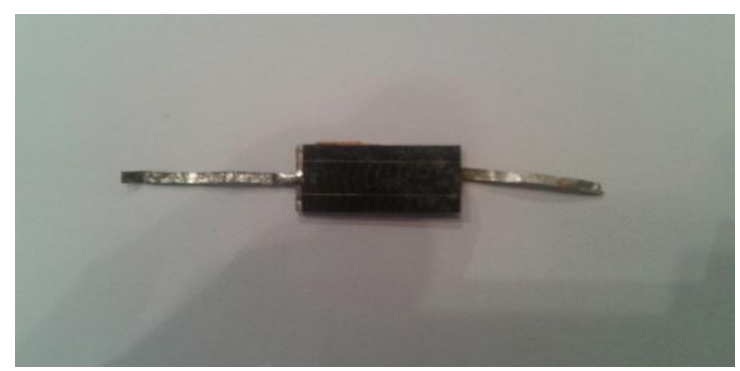

Fig. 2: Sargent-Welch silicon solar cell with area of $2.0 \mathrm{~cm}^{2}$.

The spectral response and external quantum efficiency of the mono-crystalline silicon solar cell were plotted at room temperature for the wavelength range 350-1100 nm (Fig. 3). On the other hand, the external quantum efficiency (QE) was calculated applying the well-known relation [13]:

$$
Q E(\lambda)=\frac{1}{q} \frac{h c}{\lambda} \frac{I_{S C}(\lambda)}{P(\lambda)}
$$




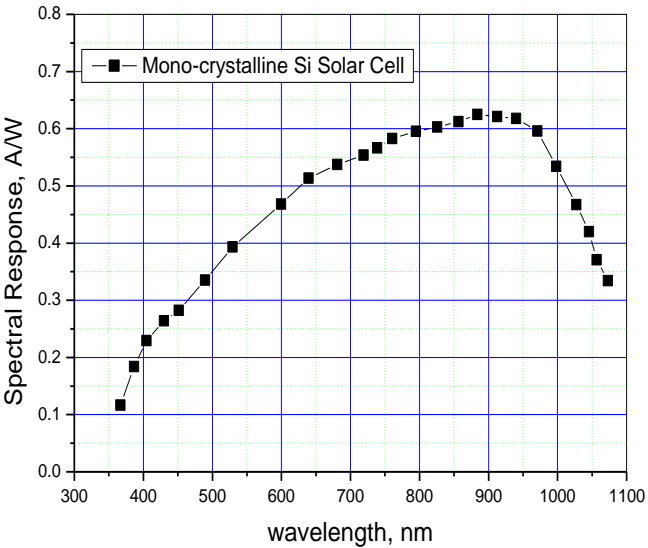

(a)

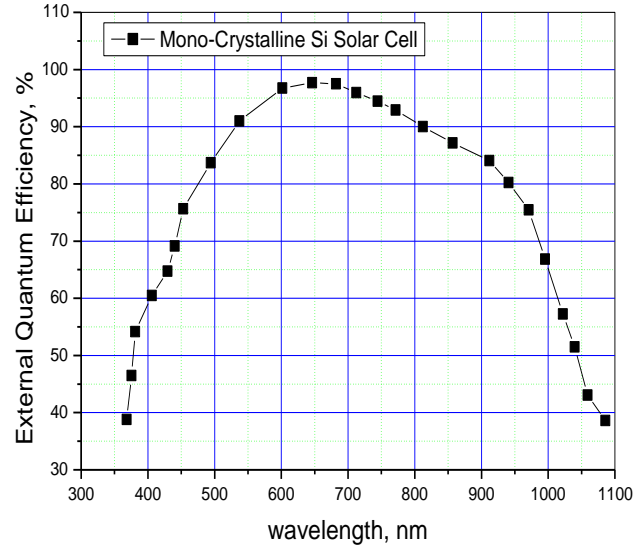

(b)

Fig. 3: Spectral response (a) and external quantum efficiency (b) of mono-Si solar cell.

\section{EXPERIMENTAL PROCEDURES}

In order to have a complete picture about the physical and electrical characteristics of the solar cells, as well the effects of the environmental conditions, it is necessary to deal with both the (I-V) - and (C-V) relationships in details.

\subsection{Current-Voltage Measurements}

Figure (4) shows the simple circuit diagram for (I-V) measurements of a prototype solar cell (a) and simple test apparatus for qualitative measurement of the (I-V) characteristic curves of the solar cells (b). Measurements were performed in an opaque enclosure to shield the solar cell from ambient light. The light source was mounted inside the enclosure, and the solar cells situated at the center point of the illumination as shown in Fig. (4). In this concern, the (I-V) characteristic curves of silicon solar cells with active areas of $2.0 \mathrm{~cm}^{2}$ were plotted under the influence of different illumination levels at room temperature, up to around 65 klux, applying different light sources (incandescent lamp, fluorescent lamp and white flood LED).

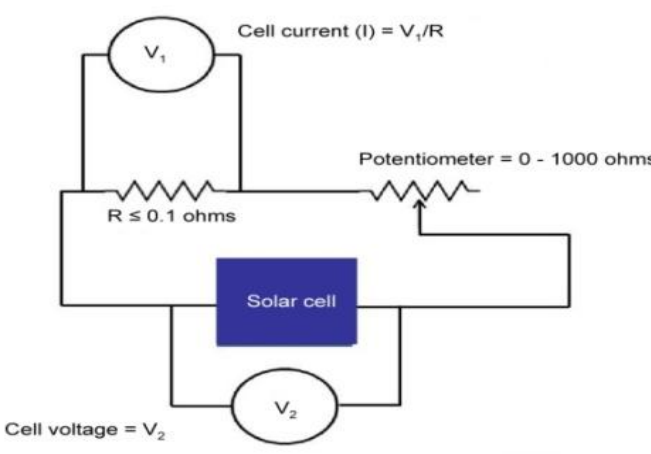

(a)

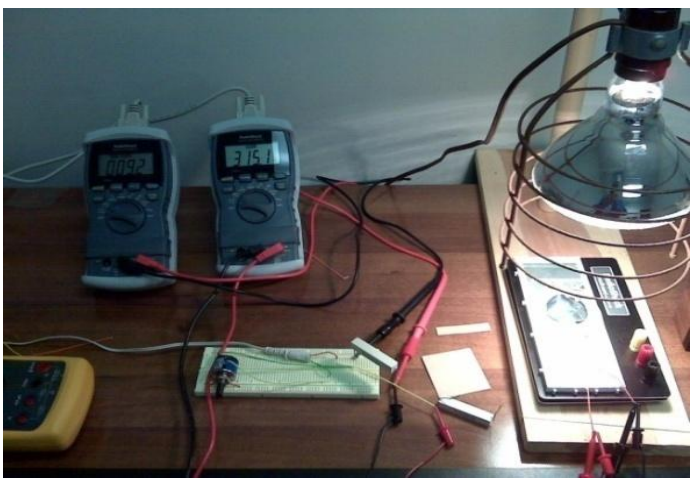

(b)

Fig. 4: (a) Simple electronic circuit used for (I-V) measurements of solar cells and (b) simple test apparatus for qualitative measurement of the (I-V) curves. 


\subsection{Capacitance-Voltage Measurements}

The programmable automatic RCL meter, model 3531 Z- HITESTER, manufactured by Hioki, was used for precise measurements of the equivalent electrical circuit parameters of the proposed solar cells (Fig. 5). It provides an auto function and ranging features, as well, it has, in short, the following specifications:

Measurement frequency: $42 \mathrm{~Hz}$ to $5.0 \mathrm{MHz}$.

Measurement levels: $10 \mathrm{mV}$ to $5.0 \mathrm{~V}$ rms (DC to $1.0 \mathrm{MHz}$ );

External interfaces: GP-IB or RS-232C.

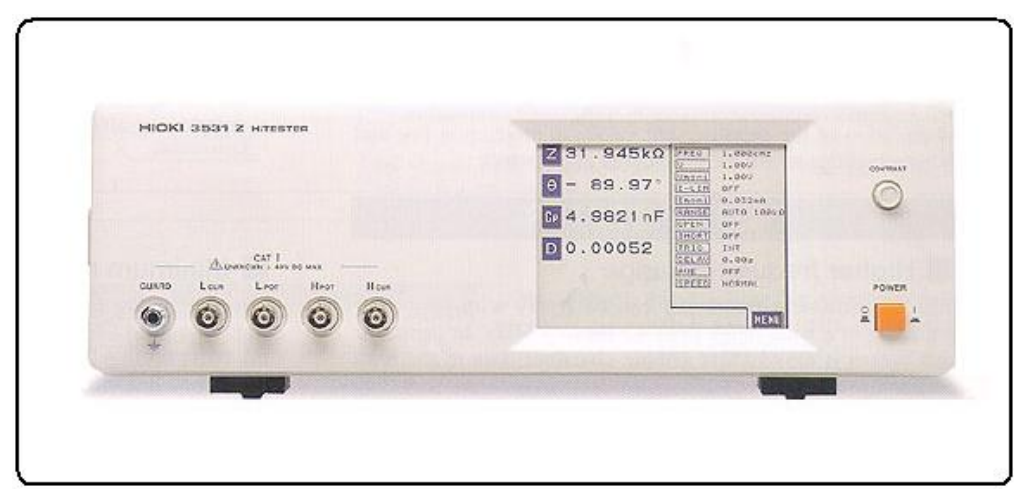

Fig. 5: Hioki 3531 Z- HITESTER.

\section{RESULTS and DISCUSSIONS}

\subsection{Static Electrical Characteristics}

Figure (6) shows the static (I-V) - and (P-V) - characteristic curves of the proposed cells, plotted at two illumination levels, as an example, applying sunlight, incandescent light lamp, white flood LED lamp and fluorescent light lamp, respectively. From which, the main electrical parameters of the solar cells $\left(I_{s c}, V_{o c}, R_{s,}, R_{s h}\right.$ $\mathrm{FF}$ and $\eta$ ) could be deduced and plotted as a function of the illumination levels (Figs. 7 through 9).
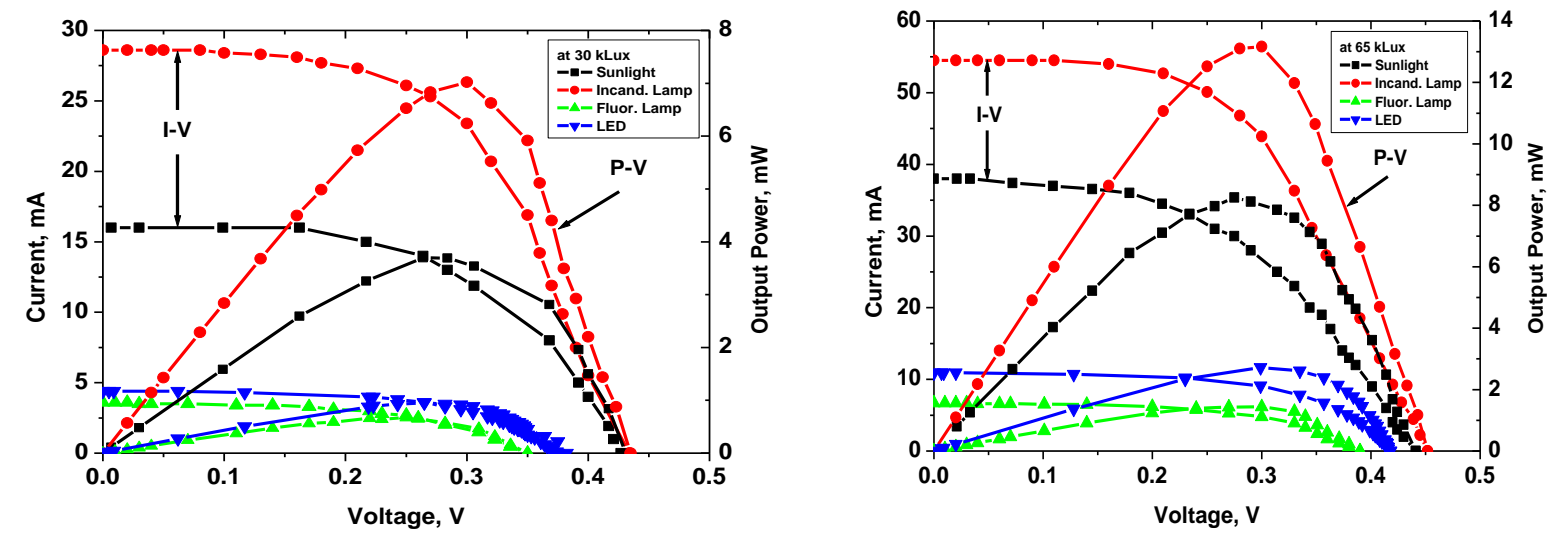

Fig. 6: Output (I-V) and (P-V) characteristic curves of mono-crystalline silicon solar cell with area of $2.0 \mathrm{~cm}^{2}$, plotted at two illumination levels applying sunlight, incandescent light lamp, white flood LED lamp and fluorescent light lamp. 
According to the photoconduction mechanism of the solar cell, the values of both $\mathrm{I}_{\mathrm{sc}}$ and $\mathrm{V}_{\mathrm{oc}}$ were plotted (Fig. 7) as a function of illumination levels to show their dependency. Considering $\mathrm{I}_{\mathrm{sc}}$ (Fig. 7a), it is shown to increase linearly as a function of the illumination levels, for all used light sources. The matter is mainly attributed to the high mobility of the carriers and the field-enhanced dissociation of exactions [14]. On the other hand, the open circuit voltage increases logarithmically as a function of light intensity (Fig. 7b and Equation 3) [15]:

$$
V_{O C}^{\prime}=V_{O C}+\frac{n k T}{q} \ln X
$$

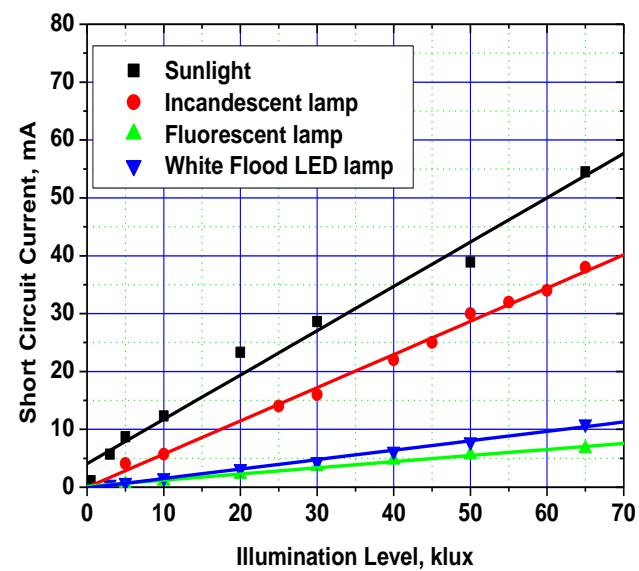

(a)

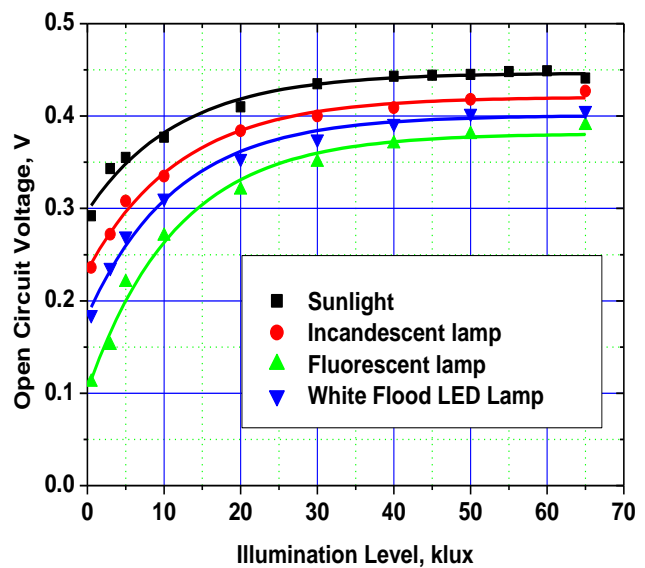

(b)

Fig. 7:Dependences of (a) short-circuit current and (b) open-circuit voltage on illumination levels applying sunlight, incandescent light, fluorescent light and White Flood LED light.

The light intensity dependence of the fill factor and efficiency was plotted for both the natural sunlight and different artificial light sources (Fig. 8).The fill factor is a measure of how far the (I-V) characteristics of an actual solar cell differ from those of an ideal cell. It is clearly shown in Fig. (8a), that the fill-factor has a value ranging between within 0.4 and 0.55 , measured for all the illumination levels. Also, Figure (8b) shows the efficiency dependence on the illumination intensity, therefore illumination levels below 10 klux, the efficiency is a direct increasing function of the illumination, the matter is mainly due to its dependence on the open circuit voltage. On the other hand, for illumination levels above 10 klux, a less efficiency dependence on illumination was observed due to open circuit voltage saturation [5]. Also, the efficiency decreasing can be attributed to increasing the recomb-ination in the semiconductor at higher temperatures [16].

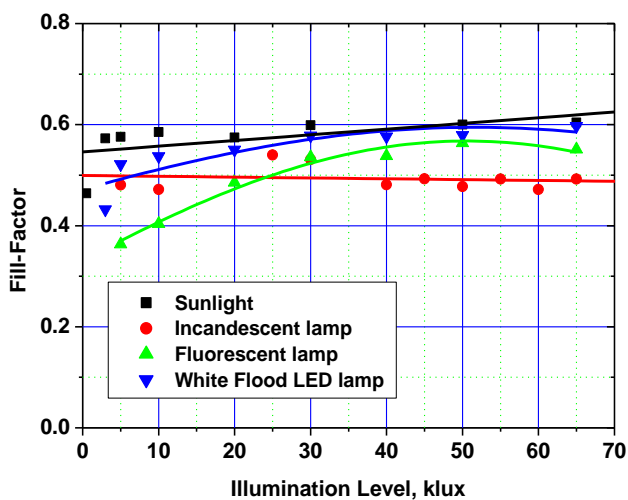

(a)

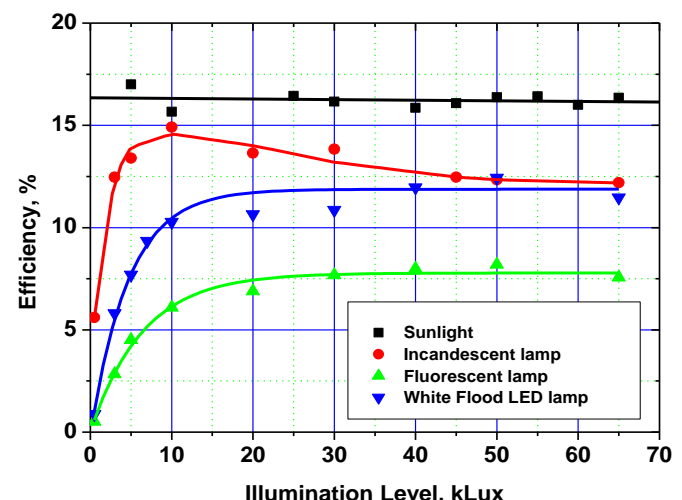

(b)

Fig. 8: Dependence of (a) fill-factor, and b) efficiency of the mono-crystalline silicon solar cell with area of $2 \mathrm{~cm}^{2}$ on illumination levels under sunlight and incandescent, fluorescent and flood LED light lamps. 
The cell series - and shunt - resistances were plotted as a function of illumination level of both the natural sunlight and that emitted applying different light sources (Fig. 9). From which, it is clear that $R_{s}$ decreases continuously with increasing the intensity of illumination (Fig. 8a), the decrease can be attributed it to the increase in conductivity of the active layer with the increase in the intensity of illumination [17]. Clearly, however, high variations of the differential resistance associated to apparent shunt resistances only occur at high irradiance intensities. This shows that accurate shunt resistance determination is difficult from (I-V) curves of illuminated solar cells. Uncertainty decreases (Fig. 9b), however, towards weaker light [18].

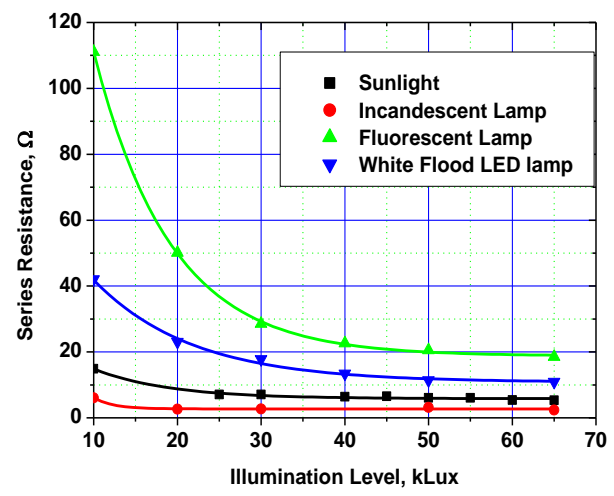

(a)

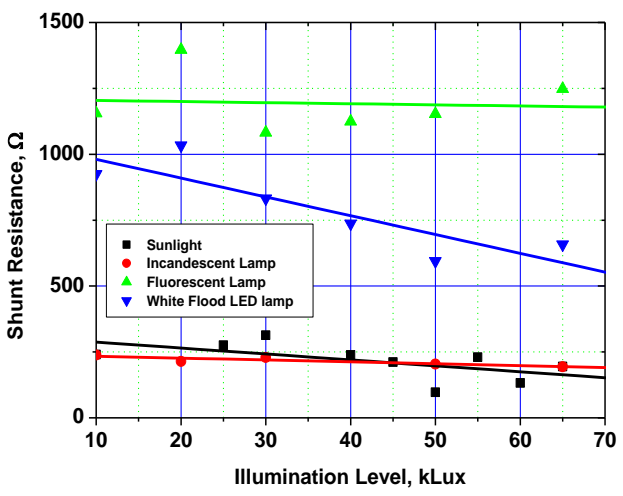

(b)

Fig. 9: Dependence of (a) series resistance, (b) shunt resistance of the mono-crystalline silicon solar cell with area of $2 \mathrm{~cm}^{2}$ on illumination levels under sunlight, incandescent, fluorescent and flood LED light lamps.

\subsection{Dynamic Characteristics}

Silicon solar cells constitute one of the main solar cell branches of the photovoltaic industry; therefore, it is important to analyze the effect of the illumination levels on their capacitive performances. When solar cells are utilized for indoor applications or integrated into a building, they are generally exposed to variable illumination levels. The performance of a solar cell is influenced by this variation as its performance parameters; capacitance, impedance, dissipation- quality- factors and phase angle. These performance parameters are in direct relationship to the cell characteristics [19]. So, the present part of the work is devoted on the capacitive characteristics whenever measured under sunlight or artificial light sources [20].

\subsubsection{Solar Cell Capacitances}

Capacitance-voltage measurements can be used to characterize fundamental properties of solar cells including an estimate of the charge carrier density. To design an efficient and reliable switching charge controller, the AC parameters of solar cells especially the cell capacitance has a need to be investigated. In this concern, the capacitance $(C)$ and depletion width $(W)$ depend on bias conditions, as explained by Eqs. $(4$, 5)[20]:

$$
\begin{gathered}
C=A \sqrt{\frac{q k_{s} \varepsilon_{o} N_{a}}{2\left(V_{b i}-V\right)}} \ldots \ldots . . . \\
W=\sqrt{\frac{2 k_{s} \varepsilon_{o}\left(V_{b i}-V\right)}{q N_{a}}}
\end{gathered}
$$

where:

$\mathrm{N}_{\mathrm{a}}$ : substrate doping density $\left(1 / \mathrm{cm}^{3}\right)$, q: electron charge $\left(1.60219 \times 10^{-19} \mathrm{C}\right), \mathrm{A}$ : area $\left(\mathrm{cm}^{2}\right)$, 
C: measured capacitance $(\mathrm{F}), \mathrm{V}$ : applied DC voltage $(\mathrm{V}), \mathrm{W}$ : depletion width $(\mathrm{cm}), V_{\text {bi }}$ : built-in potential $(\mathrm{V}), \mathrm{k}_{\mathrm{s}}$ : relative permittivity, $\varepsilon_{0}$ : vacuum permittivity.

An estimation of the charge carrier density $\left(\mathrm{N}_{\mathrm{a}}\right)$ of silicon solar cell could be deduced from Mott-Schottky plot - $\left(1 / C^{2}\right)$ versus bias voltage [21] presented in Fig. (10). It could be calculated using Eq. (1).

Figure (10) shows the experimental results of (C-V) characteristic curves of the proposed solar cell, plotted for both forward -and reverse - biasing modes, at different frequency values ranging from $20 \mathrm{kHz}$ up to $140 \mathrm{kHz}$, as well the doping (charge carrier) density of a silicon solar cell. All measurements are made at dark, illuminated with cold white flood LED and incandescent lamp at 5.0 klux for example. From which, it can be seen that the capacitance $\left(C_{D}\right)$ increases with forward bias and decreases with increasing frequency. On the other hand, it $\left(C_{T}\right)$ decreases with reverse bias and does not depend on frequencies. If the depletion region was formed by sufficient reverse bias, then the variation of depletion width by the (AC) signal will be negligible. In the case of forward bias conditions at lower frequencies, carriers can easily follow the AC signal. However, in high-frequency conditions, carriers cannot easily react to the AC signal [20]. So we can recognize the frequency dependence of this device from Fig. (10).

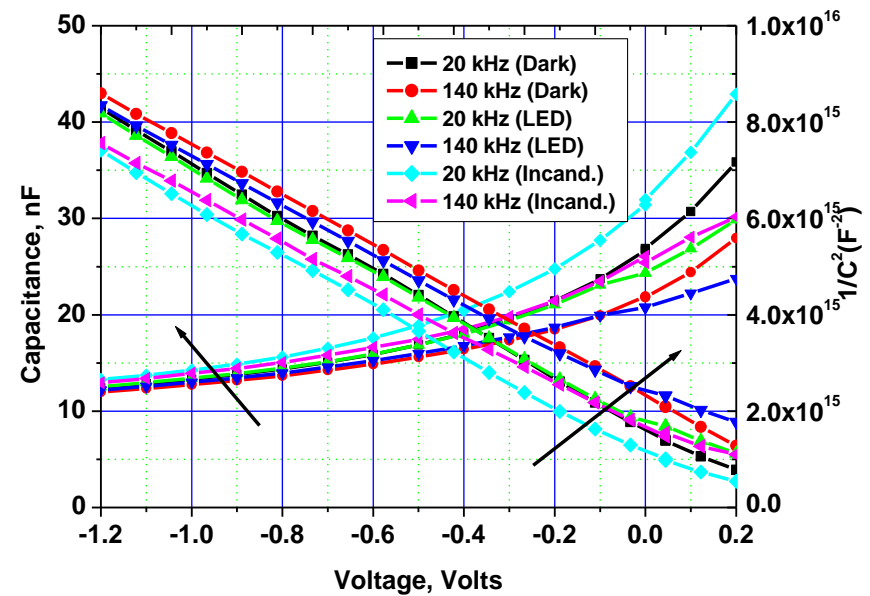

Fig. 10: C-V and $1 / C^{2}-V$ characteristics of silicon solar cell under dark, white flood LED and incandescent Lamp.

From the given $(\mathrm{C}-\mathrm{V})$ characteristic curves, the charge carrier concentration and built-in voltage could be obtained as shown in Table (1) and Fig. (11).

Table 1. Charge carriers concentration and built-in voltage of mono-crystalline silicon solar cell, calculated for different light sources.

\begin{tabular}{|c|c|c|}
\hline Light sources & $\begin{array}{c}\text { Charge carrier } \\
\text { concentration, charge } / \mathrm{cm}^{3} \\
\text { and } S D(E r \pm)\end{array}$ & $\begin{array}{c}\text { Built-in voltage, V } \\
\text { and SD (Er } \pm)\end{array}$ \\
\hline Dark & $1.44864 \mathrm{E} 15 \pm 0.0702$ & $0.47089 \pm 0.05$ \\
\hline White Flood LED & $1.44743 \mathrm{E} 15 \pm 0.0548$ & $0.50178 \pm 0.038$ \\
\hline Incandescent Lamp & $1.46038 \mathrm{E} 15 \pm 0.0265$ & $0.531 \pm 0.0328$ \\
\hline
\end{tabular}




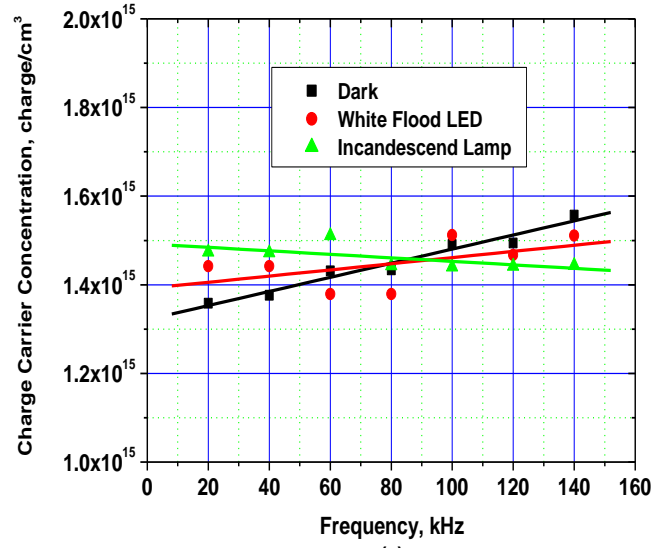

(a)

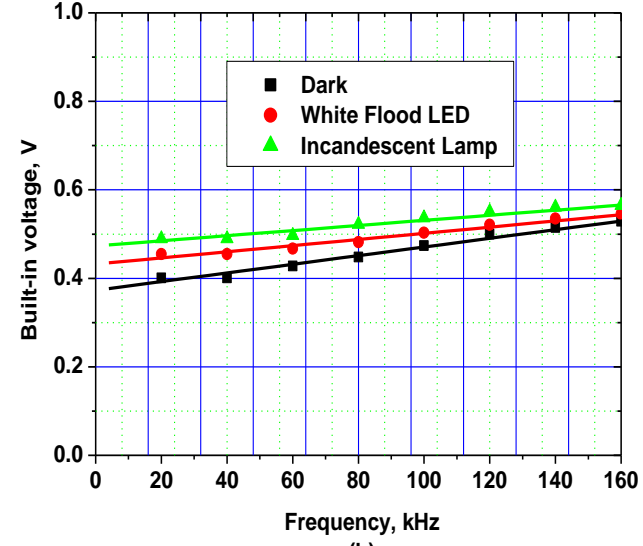

(b)

Fig. 11: Charge carrier concentration (a) and built-in voltage (b) of silicon solar cell measured with frequency range of $20 \mathrm{kHz}$ to $140 \mathrm{kHz}$.

\subsubsection{Impedance}

Photovoltaic modules are operated as dc-devices, but they exhibit impedance $(Z)$ due to their cells design, the matter which arise the needs for a detailed study on ac-parameters. It is an important parameter that has been found to depend on bias voltages and frequencies [20, 22, 23]. In the present study, the characteristic impedance is analyzed at two different frequency levels of $20 \mathrm{kHz}$ and $140 \mathrm{kHz}$, and at different bias voltage from $-1.2 \mathrm{~V}$ to $0.6 \mathrm{~V}$ for dark, cold white flood LED and incandescent lamp at $5.0 \mathrm{klux}$, as an example (Fig. 12).

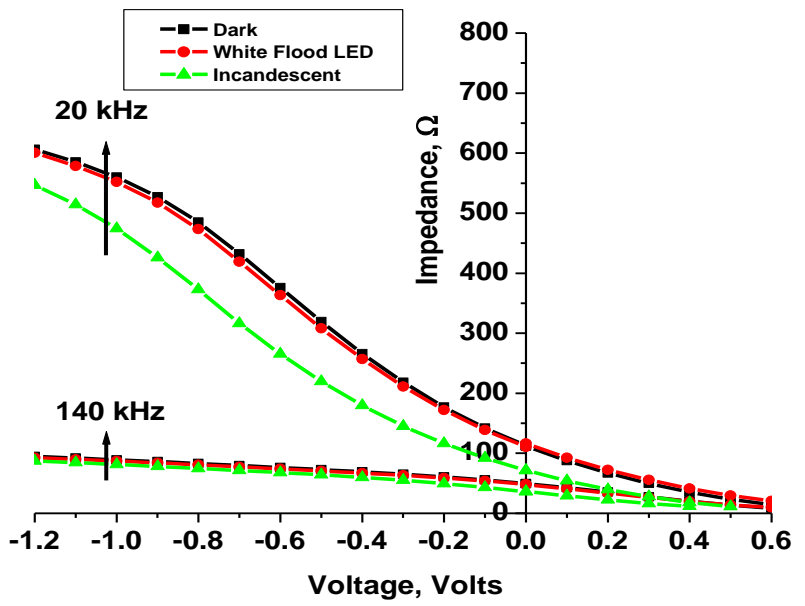

Fig. 12: Impedance of silicon solar cell vs. voltage for (Dark, Incandescent Lamp and White Flood LED).

Figure (12) presents higher impedance values at lower frequencies i.e. for direct current signals which have lower frequencies have been blocked by the junction capacitor. So the impedance increases with decreasing frequency but the impedance decreases as a function of bias voltage. On the other hand, at a frequency value of $140 \mathrm{kHz}$, we confirmed the minimum value of impedance according to the degradation of the reactance factor. 


\subsubsection{Quality Factor}

The quality factor $(\mathrm{Q})$, which is considered as a figure of merit of the solar cell is an important parameter. It can be expressed as the ratio of the total reactance of the junction to its resistance and is governed [24] by the following Eq. (6).

$$
Q=2 \pi f C R
$$

In this concern, quality factor was experimentally measured at two frequency value $20 \mathrm{kHz}$ and $140 \mathrm{kHz}$ for both forward and reverse bias modes of operation at dark and light intensity of 5.0 klux (Fig. 13). Also, it can be seen from Fig. (13) that the quality factor decreases with forward bias and increases with higher frequencies. On the other hand, in reverse bias conditions, it increases with increasing frequencies. It could be concluded that the quality factor is a voltage- and frequency- dependent.

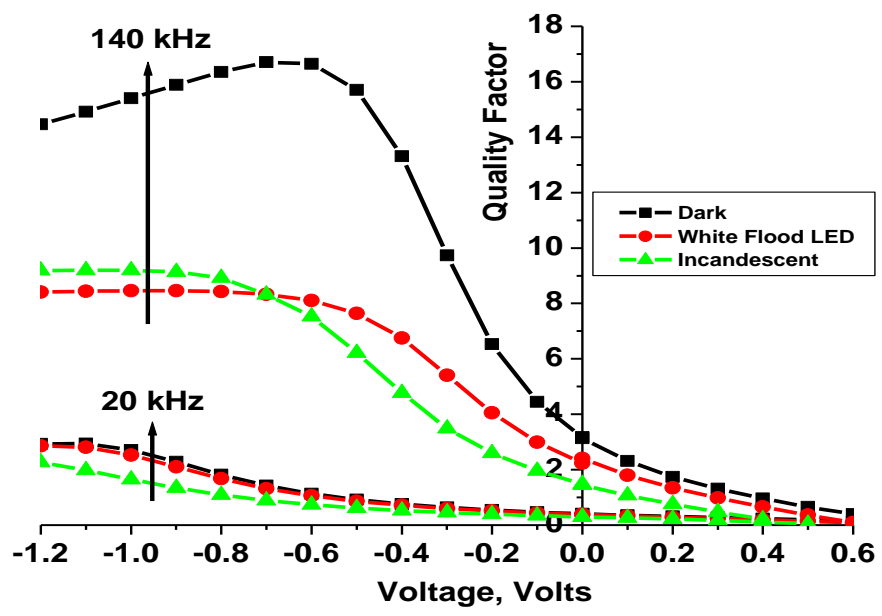

Fig. 13: Quality factor of silicon solar cell vs. voltage for (Dark, Incandescent Lamp and White Flood LED).

\subsubsection{Dissipation Factor}

The dissipation factor (D) is an important parameter for device performance and is considered as the reciprocal of quality factor. It can be governed by the following equation [24]:

$$
\mathrm{D}=\frac{1}{Q}=\frac{1}{2 \pi f C R}
$$

Figure (14) shows the experimental results of (D-V), plotted at two frequency values of $20 \mathrm{kHz}$ and $140 \mathrm{kHz}$ in both reverse and forward bias conditions at dark and light intensity of 5.0 klux. As can be seen in Fig. (14), the dissipation factor increases with forward bias and decreases in reverse bias conditions. On the other hand, it decreases with increasing frequencies in both bias conditions. 


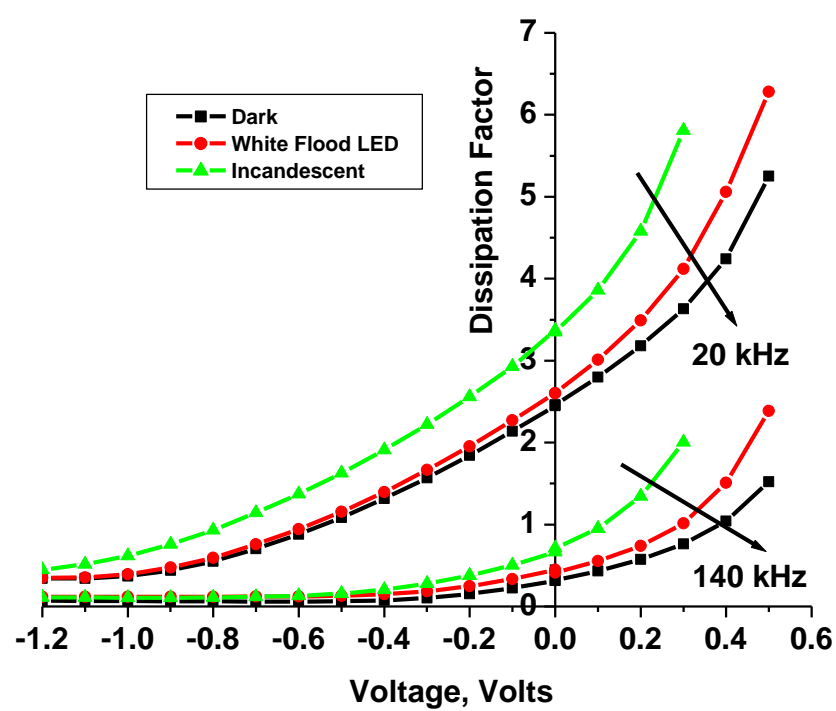

Fig. 14: Dissipation factor of silicon solar cell vs. voltage for (Dark, Incandescent Lamp and White Flood LED).

\subsubsection{Phase Angle}

The phase angle $(\varphi)$ is the angle between the current passing through the junction and the applied voltage and is given by the ratio of total reactance to total ohmic resistance and it can be expressed by the following equation [24].

$$
\tan \theta=\frac{X_{c}}{R}
$$

Figure (15) shows the measured phase angle dependence on the bias voltage conditions at two frequency values of $20 \mathrm{kHz}$ to $140 \mathrm{kHz}$ at dark and light intensity of $5.0 \mathrm{klux}$.

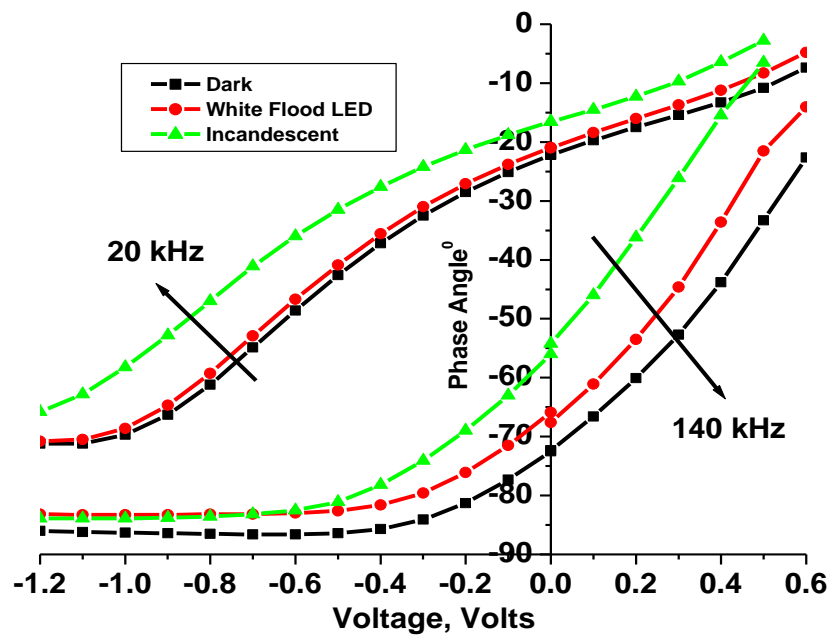

Fig. 15: Phase angle of silicon solar cell vs. voltage for (Dark, Incandescent Lamp and White Flood LED). 
It can be seen in Fig. (15) the phase angle presents higher values at lower frequencies. It increases with forward bias, while it decreases with increasing reverse bias and does not depend mainly at a higher reverse bias voltage. Moreover, it reaches a value of around $-85^{\circ}$ with higher signal frequency at very low bias voltages i.e. it behaves like a capacitor.

\subsection{Effect of Temperature on Solar Cell Characteristics}

Solar cell properties can be altered by changes in environmental conditions such as temperature. The tested solar cell is investigated at the temperature range between 30 to $110^{\circ} \mathrm{C}$ at dark [25]. In this work, a monocrystalline silicon solar cell of $(1 \times 2) \mathrm{cm}^{2}$ area was used employing solar cell simulator with cell temperature in the range $30-110{ }^{\circ} \mathrm{C}$ at constant light intensities $1-70 \mathrm{~mW} / \mathrm{m}^{2}$ of simulated Infrared lamp (IR-Osram) lamp. The light intensity or irradiance of the IR lamp can be varied [26]. Temperature dependency of solar all the cells performance parameters are investigated.

\subsubsection{Effect of Temperature on the Electrical Characteristics of Solar Cell}

The electrical characteristics of the solar cell samples were plotted at different temperature levels ranging from $30{ }^{\circ} \mathrm{C}$ up to $110{ }^{\circ} \mathrm{C}$ (Fig. 16). Increases in temperature reduce the band gap of a solar cell, whereby effecting the solar cell electrical parameters [25].

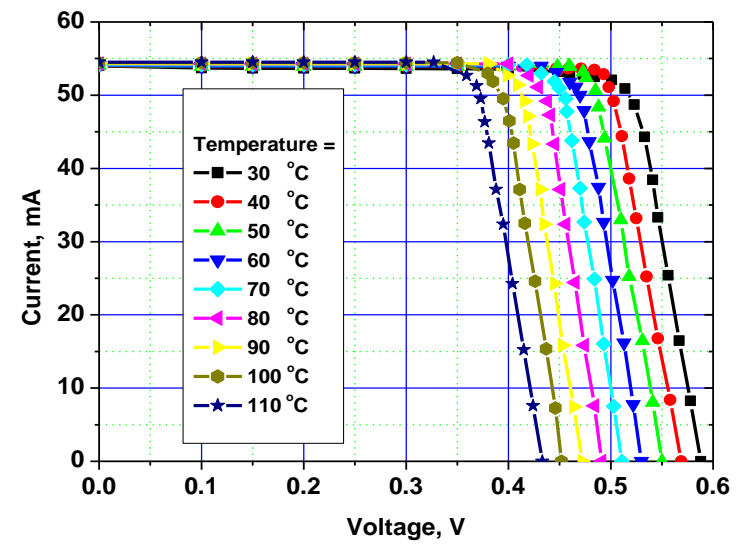

Fig. 16: Voltage-current characteristics of solar cell under different temperature.

Like all other semiconductor devices, solar cells are sensitive to temperature. Increases in temperature reduce the band gap of a semiconductor, thereby effecting most of the semi-conductor material parameters. The decrease in the band gap of a semiconductor with increasing temperature can be viewed as increasing the energy of the electrons in the material. Lower energy is therefore needed to break the bond. In the bond model of a semiconductor band gap, reduction in the bond energy also reduces the band gap. Therefore, increasing the temperature reduces the band gap.

In a solar cell, the parameter most affected by an increase in temperature is the open-circuit voltage. The impact of increasing temperature is shown in the figure below. The open-circuit voltage decreases with temperature because of the temperature dependence of $I_{0}$. The equation for $I_{0}$ from one side of a $p-n$ junction is given by;

$$
I_{o}=q A \frac{D n_{i}^{2}}{L N_{D}}
$$

where, $A$ is the area of sample, $D$ is the diffusivity of the minority carrier, $n_{i}$ is the intrinsic carrier concentration, $L$ is the diffusion length of the minority carrier, and $N_{D}$ is the doping concentration in $\mathrm{n}$ region. 
In the above equation, many of the parameters have some temperature dependence, but the most significant effect is due to the intrinsic carrier concentration, $\mathrm{n}_{\mathrm{i}}$. The intrinsic carrier concentration depends on the band gap energy (with lower band gaps giving a higher intrinsic carrier concentration), and on the energy which the carriers have (with higher temperatures giving higher intrinsic carrier concentrations). The equation for the intrinsic carrier concentration is;

$$
n_{i}^{2}=4\left(\frac{2 \pi k T}{h^{2}}\right)^{3}\left(m_{e}^{*} m_{h}^{*}\right)^{3 / 2} \exp \left(-\frac{E_{G o}}{k T}\right)=B T^{3} \exp \left(-\frac{E_{G o}}{k T}\right)
$$

where, $T$ is the temperature, $h$ and $k$ are constants, $m_{e}$ and $m_{h}$ are the effective masses of electrons and holes respectively, $\mathrm{E}_{\mathrm{Go}}$ is the band gap linearly extrapolated to absolute zero; and $\mathrm{B}$ is a constant which is essentially independent of temperature.

Substituting these equations back into the expression for $I_{0}$, and assuming that the temperature dependencies of the other parameters can be neglected, gives;

$$
I_{o}=q A \frac{D}{L N_{D}} B T^{3} \exp \left(-\frac{E_{G o}}{k T}\right) \approx B^{\prime} T^{\gamma} \exp \left(-\frac{E_{G o}}{k T}\right) \ldots
$$

where $B^{\prime}$ is a temperature independent constant. A constant, $\gamma$, is used instead of the number 3 to incorporate the possible temperature dependencies of the other material parameters. For silicon solar cells near room temperature, $I_{0}$ approximately doubles for every $10{ }^{\circ} \mathrm{C}$ increase in temperature. The impact of $I_{0}$ on the opencircuit voltage can be calculated by substituting the equation for $I_{0}$ into the equation for $V_{\text {oc }}$ as shown below;

$$
\begin{aligned}
& V_{O C}=\frac{k T}{q} \ln \left(\frac{I_{S C}}{I_{o}}\right)=\frac{k T}{q}\left[\ln I_{S C}-\ln I_{o}\right]=\frac{k T}{q} \ln I_{S C}-\frac{k T}{q} \ln \left[B^{\prime} T^{\gamma} \exp \left(-\frac{q V_{G o}}{k T}\right)\right] \\
& =\frac{k T}{q}\left(\ln I_{S C}-\ln B^{\prime}-\gamma \ln T+\frac{q V_{G o}}{k T}\right)
\end{aligned}
$$

Where, $E_{G o}=q_{G_{0}}$. Assuming that $d V_{o c} / d T$ does not depend on $d_{s c} / d T, d V_{o c} / d T$ can be found as;

$$
\frac{d V_{O C}}{d T}=\frac{V_{O C}-V_{G o}}{T}-\gamma \frac{k}{q}
$$

The above equation shows that the temperature sensitivity of a solar cell depends on the open circuit voltage of the solar cell, with higher voltage solar cells being less affected by temperature. For silicon, $\mathrm{E}_{\mathrm{Go}}$ is 1.2 , and using $\gamma$ as 3 gives a reduction in the open-circuit voltage of about $2.2 \mathrm{mV} /{ }^{\circ} \mathrm{C}$;

$$
\frac{d V_{O C}}{d T}=-\frac{V_{G o}-V_{O C}+\gamma \frac{k T}{q}}{T} \approx-2.2 \mathrm{mV} \text { per }{ }^{o} \mathrm{C} \text { for } \mathrm{Si}
$$

The short-circuit current, $I_{s c}$ increases slightly with temperature, since the band gap energy, $E_{G}$ decreases and more photons have enough energy to create e-h pairs. However, this is a small effect and the temperature dependence of the short-circuit current from a silicon solar cell is;

$$
\frac{1}{I_{S C}} \frac{d I_{S C}}{d T} \approx 0.0006 \text { per }^{o} C \text { for } S i
$$

The temperature dependency FF for silicon is approximated by the following equation; 


$$
\frac{1}{F F} \frac{d F F}{d T} \approx\left(\frac{1}{V_{O C}} \frac{d V_{O C}}{d T}-\frac{1}{T}\right) \approx-0.0015 \text { per }^{\circ} C \text { for } S i
$$

The effect of temperature on the maximum power output, $P_{m}$, is;

$$
\begin{aligned}
& P_{M \mathrm{var}}= \frac{1}{P_{M}} \frac{d P_{M}}{d T}=\frac{1}{V_{O C}} \frac{d V_{O C}}{d T}+\frac{1}{F F} \frac{d F F}{d T}+\frac{1}{I_{S C}} \frac{d I_{S C}}{d T} . \\
& \frac{1}{P_{M}} \frac{d P_{M}}{d T} \approx-(0.004 \text { to } 0.005) \text { per }{ }^{o} C \text { for } S i
\end{aligned}
$$

Most semiconductor modeling is done at $300 \mathrm{~K}$ since it is close to room temperature and a convenient number. However, solar cells are typically measured almost 2 degrees lower at $25^{\circ} \mathrm{C}(298.15 \mathrm{~K})$. In most cases, the difference is insignificant (only $4 \mathrm{mV}$ of $\mathrm{V}_{\text {oc }}$ ) and both are referred to as room temperature. Occasionally, the modeled results need to be adjusted to correlate with the measured results [27]

From Fig. (16), fundamental parameters of solar cells like short-circuit current ( $\left.\mathrm{I}_{\mathrm{sc}}\right)$, open-circuit voltage $\left(\mathrm{V}_{\text {oc }}\right)$, maximum output power $\left(P_{\max }\right)$, fill factor (FF) and efficiency $(\eta)$ could be extracted. Also, Figures (17-a and-b) show the temperature dependence, in the range from $30^{\circ} \mathrm{C}$ up to $110^{\circ} \mathrm{C}$, of both the short-circuit current $\left(\mathrm{I}_{\mathrm{sc}}\right)$ and open-circuit voltage $\left(\mathrm{V}_{\mathrm{oc}}\right)$. The dependence of $\left(\mathrm{I}_{\mathrm{sc}}\right)$ on the temperature is very small, and it is attributed to a temperature coefficient of $6.5 \mu \mathrm{A} /{ }^{\circ} \mathrm{C}$. On the other hand, the $\left(\mathrm{V}_{\mathrm{oc}}\right)$ was observed to decrease with increasing temperature, with decreasing rate of $2.0 \mathrm{mV} /{ }^{\circ} \mathrm{C}$ which confirms with that value of a normal $p-n$ junction. Where with the increase in temperature the rate of photon generation increases, thus the reverse saturation current increases rapidly, leading to reduction in the band gap. Hence, this leads to marginal changes in current but major changes in voltage [28].

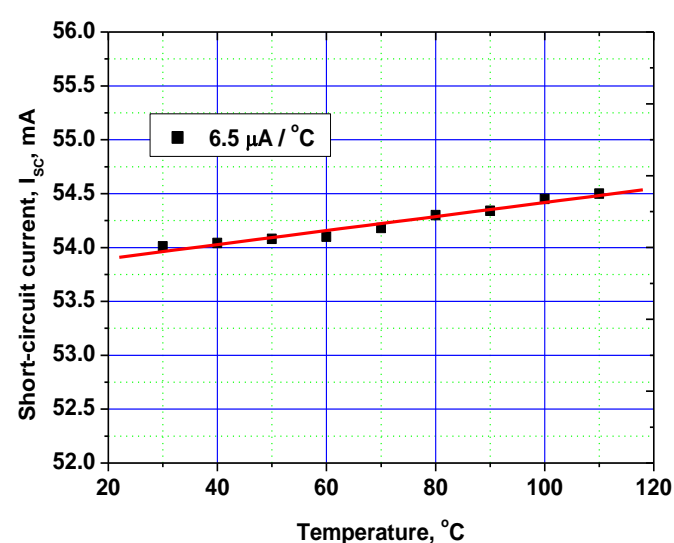

(a)

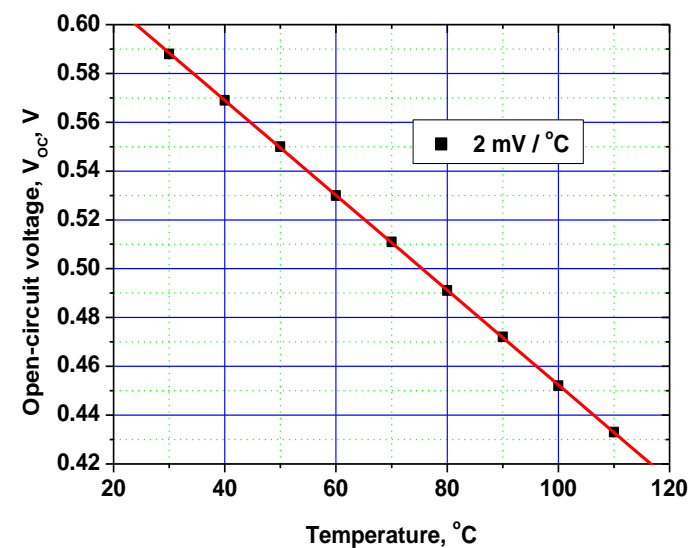

(b)

Fig. 17: Short-circuit current (a) and Open-circuit voltage (b) of solar cell under different temperature.

Figure (18) shows the effect of temperature on the maximum output power is menus $0.079 \mathrm{~mW} /{ }^{\circ} \mathrm{C}$. 


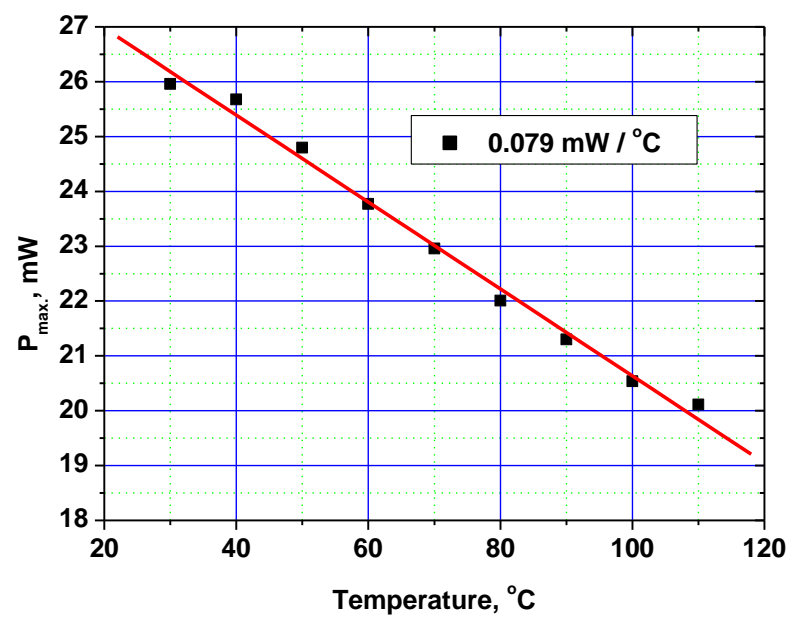

Fig. 18: Maximum output power of solar cell under different temperature.

Figure (19) shows the effect of temperature on the fill factor and efficiency, where both factors were shown to be decreased with increasing temperature from $30^{\circ} \mathrm{C}$ to $110^{\circ} \mathrm{C}$. As shown in Fig. (19a) the Fill factor decreases with increasing temperature. The decrease in fill factor is mainly controlled by a decrease in $\mathrm{V}_{\mathrm{OC}}$ whereas an increase in short circuit current with temperature does not contribute much to fill factor [29]. When the temperature dependence of solar cell characteristics are concerned, although an increase of the current with the temperature increase was observed, main output characteristics such as efficiency were negatively influenced by high temperature (Fig. 19b). This is due to the fact that open circuit voltage rapidly decreases with an increase of the temperature, as could be seen in Fig. (17b).

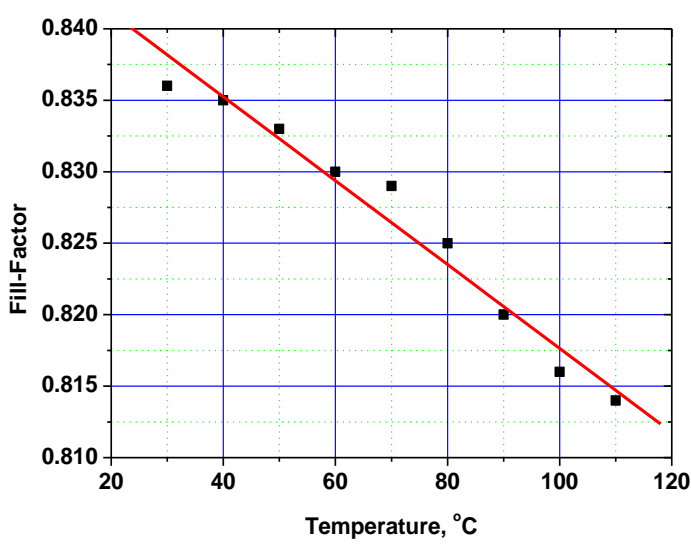

(a)

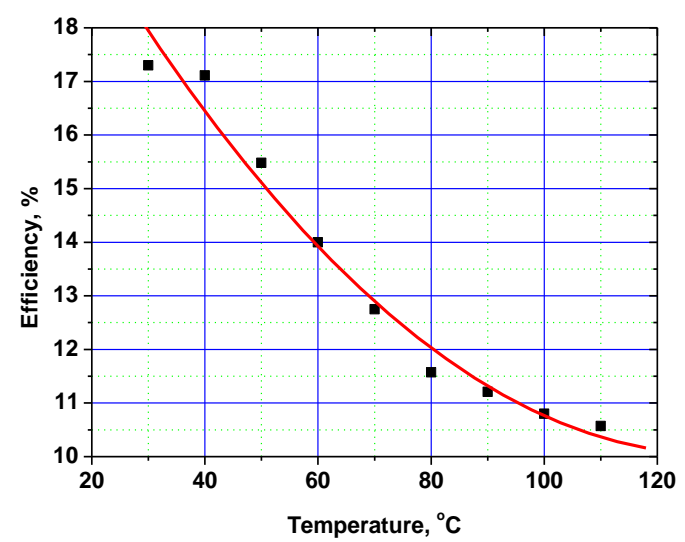

(b)

Fig. 19: Fill factor (a) and efficiency (b) of solar cell under different temperature.

\subsubsection{Effect of Temperature on Capacitance Characteristics of Solar Cell}

\subsubsection{Effects on Junction Capacitance}

The variation of $C_{j}$ with temperature can be varied over the range of 30 to $110{ }^{\circ} \mathrm{C}$ as depicted in Fig. (20). It is clearly visible that the junction capacitance depends on the cell temperature in the forward bias it increases with increasing temperature. On the other hand, it decreases with reverse bias voltage i.e. solar cell capacitance can be used to measure temperature [30]. The junction capacitance of a solar cell (any $p-n$ junction) is given by a general formula: 


$$
\begin{gathered}
C_{j}=\frac{B_{0}}{\left(V_{0}-V_{d}\right)^{n}} \ldots . . . \\
\left|C_{j}\right|=\frac{I \cdot \tau}{\left(V_{0}-V_{d}\right)^{n}}
\end{gathered}
$$

Where $I$ : current, $\tau$ : carrier life time, $C_{j}$ : junction capacitance, $B_{0}$ : a constant, $V_{d}$ : applied bias potential, $V_{0}$ : function of temperature and varies in a complex way depending on doping concentration.

$$
V_{0}=\frac{k T}{q} \ln \frac{N_{D} N_{A}}{n_{i}^{2}}
$$

where, $N_{A}$ is the doping concentration in the p-region,

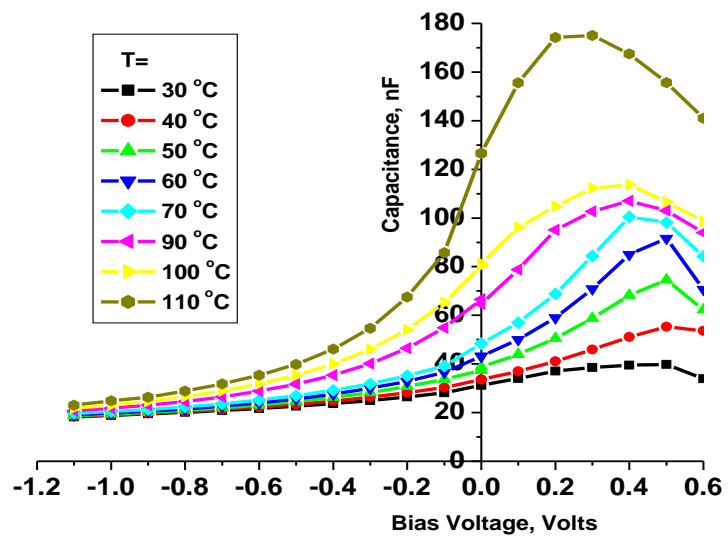

Fig. 20: Changes in solar cell capacitance with bias voltage at different temperature.

\subsubsection{Effect on Junction Impedance}

Solar cell impedance is directly affected by the temperature as shown in Fig. (21). As the temperature is increased the impedance decreases at forward bias conditions, while it decreases strongly with increasing temperature at reverse bias conditions. The junction impedance is directly related to the cell capacitance which depends on temperature as it clear from the following equation [20].

$$
Z=R+1 / j \omega C
$$

where:

Z: impedance,

$\omega(=2 \pi f)$ : angular frequency,

$1 / j \omega C$ : reactance, and

$R$ : resistance. 


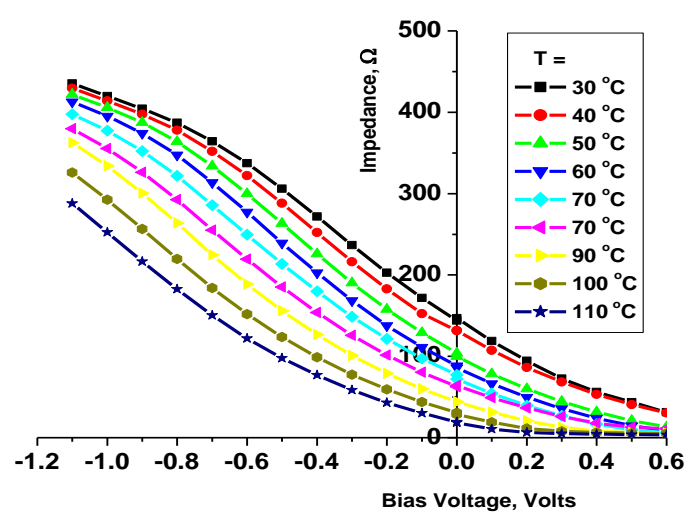

Fig. 21: Changes in solar cell impedance with bias voltage at different temperature.

\subsubsection{Effects on Quality- and- Dissipation factors}

Figure (22) presents solar cell quality factor (Q) and dissipation factor (D) changes with bias voltages at different temperature values. According to Eqs. $(7,8)$, it is clearly shown that $(\mathrm{Q})$ factor is a direct function of cell capacitance, whereas (D) factor is inversely (Fig. 22).

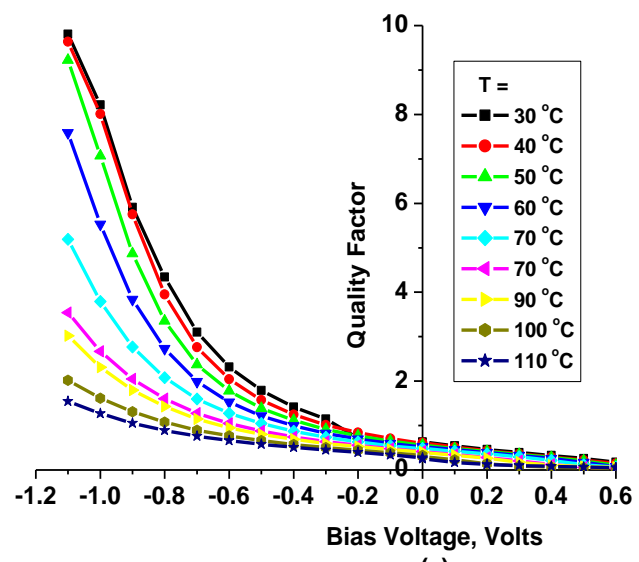

(a)

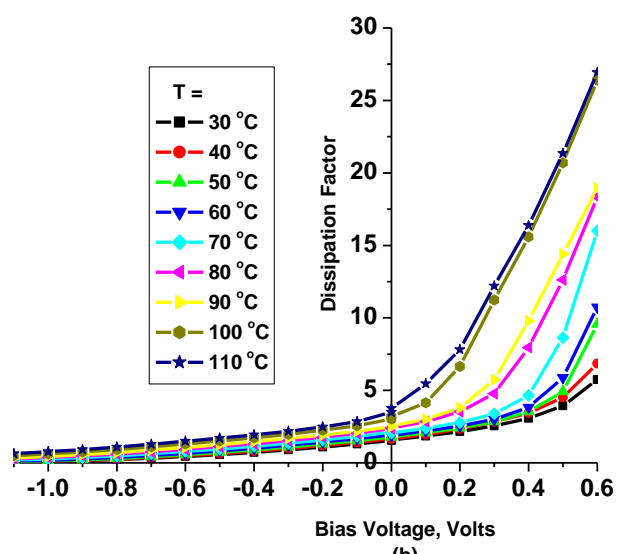

\section{Fig. 22: Changes in solar cell (a) quality and (b) dissipation factors with bias voltage at different temperature.}

\subsubsection{Effect on Phase Angle}

According to Eq. (9) and Fig. (23), it is clearly shown that the solar cell phase angle $(\varphi)$ increases in positive direction i.e. less in negativity with increasing temperature, so it could be concluded that the solar cell does not behave like a capacitor. 


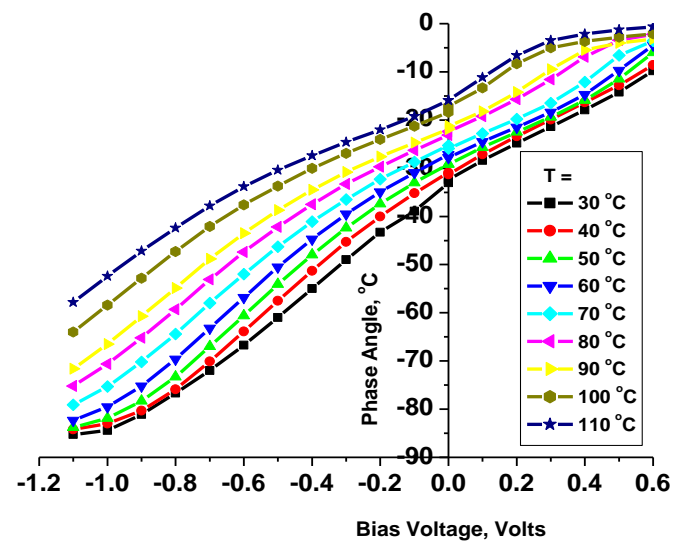

Fig. 23: Changes in solar cell phase angle with bias voltage at different temperature.

\section{CONCLUSIONS}

In this paper, the silicon solar cell performances based on (I-V) - and (C-V) - characteristics were investigated under the influence of different environmental conditions. The static (I-V) - and dynamic (C-V) - electrical characteristics of mono-crystalline solar cells were tested, analyzed and reported under the influence of illumination type, intensity and wavelength, as well temperature. The dependence of electrical cell parameters $\left(V_{o c}, I_{s c}, F F, R_{s}\right.$ and $\left.R_{s h}\right)$, on the illumination level were investigated for a wide illumination intensity range 1.0 $70 \mathrm{~mW} / \mathrm{cm}^{2}$. According to the photoconduction mechanism of the solar cell, it is observed that, $V_{o c}, R_{s h}, F F$ and efficiency, were shown to be saturated for illumination levels higher than $10 \mathrm{klux}$. On the mean time, $\mathrm{I}_{\mathrm{sc}}$ was shown to be increased linearly due to the high mobility of the carriers and the field-enhanced dissociation of exaction, while $R_{s}$ was decreased exponentially.

The capacitance-voltage (C-V) characteristics of the cells were plotted under both the forward - and reverse biasing modes, at different frequency levels within the range of $20 \mathrm{kHz}-140 \mathrm{kHz}$, and different illumination levels. From which, $\mathrm{V}_{\mathrm{bi}}$, and $\mathrm{N}_{\mathrm{a}}$, were determined, where $\mathrm{V}_{\mathrm{bi}}$ values of $0.471,0.502$ and 0.531 Volts and $\mathrm{N}_{\mathrm{a}}$ values of $1.449 \mathrm{E} 15,1.447 \mathrm{E} 15$ and $1.460 \mathrm{E} 15$ charge $/ \mathrm{cm}^{3}$ were reported at dark, white flood LED and incandescent, respectively.

Finally, the obtained results, it could be concluded that the performances of solar cells are dependent on the operating environment, where, almost all their static - and dynamic- electrical parameters were proved to be function of temperature level. Reduction in the open-circuit voltage for silicon solar cells is about $2 \mathrm{mV} /{ }^{\circ} \mathrm{C}$. As well as the effect of temperature on the maximum power output $-0.079 \mathrm{mw} /{ }^{\circ} \mathrm{C}$. As well, the parameters $C$ and $D$ were shown to increase, while $Z, Q$, and $\varphi$ decrease with temperature increase.

\section{REFERENCES}

1. Jean Zaraket, Michel Aillerie and ChaficSalame, "Capacitance evolution of photovoltaic solar modules under the influence of electrical stress", Energy Procedia, 2015, 74, pp. $1466-1475$.

2. PankajYadav, BrijeshTripathi, KavitaPandeyandManoj Kumar, "Recombination kinetics in a silicon solar cell at low concentration: electro-analytical characterization of space-charge and quasi-neutral regions", Phys. Chem. Chem. Phys., 2014, Vol. (16), pp. 15469-15476.

3. C Protogeropoulos, I Klonaris, C Petrocheilos, I Charitos, and I Martinac, 6-10 September 2010," Performance evaluation of different PV module technologies in a grid-connected pilot project in greece", $25^{\text {nd }}$ European Photovoltaic Solar Energy Conference, pp. 4601- 4606, Valencia, Spain. 
4. L.A. Dobrzański, M. Szczęsna, M. Szindler, A. Drygała, "Electrical properties mono- and polycrystalline silicon solar cells", Journal of Achievements in Materials and Manufacturing Engineering, August 2013, Vol. (59), Issue (2), pp. 67-74.

5. M. Chegaar, A. Hamzaoui, A. Namoda, P. Petit, M. Aillerie, and A. Herguth, 2013, " Effect of illumination intensity on solar cells parameters", Energy Procedia, Vol. (36), pp. $722-729$.

6. N. Silsirivanich, D. Chenvidhy, K. Kirtikara, K. Sriprapha, J. Sritharathikhun, R. Songprakorp, and C. Jivacate, " Nonstationary effects at photovoltaic module characterization using pulsed solar simulator", Journal of Applied Spectroscopy, March-April 2015, Vol. (82), No. (2), pp. 286- 292.

7. Johan Verschraegen, Marc Burgelman, JurgenPenndorf, 2004, "Interpretation of capacitance measurements in CuInS-on-Cu-tape solar 2 cells", Thin Solid Films, 451 - 452, pp. 179-183.

8. M. Ashry, S. Fares, "Electrical characteristic measurement of the fabricated CdSe / P-Si heterojunction solar cell under radiation effect", American Journal of Materials Science, 2012, Vol. (2), No. (3), pp. $72-$ 76.

9. Chin, V. W. L. and Newbury, S. M., "Determination of barrier height and doping density of a Schottky diode from infrared photoresponse measurements", Australian Journal of Physics, 1992, Vol. (45), pp. 781-787.

10. Y. Li , N.J. Grabham, S.P. Beeby, M.J. Tudor, "The effect of the type of illumination on the energy harvesting performance of solar cells", 2015, Solar Energy, Vol. (111), pp. 21-29.

11. Ben Minnaert and Peter Veelaert, "A Proposal for Typical Artificial Light Sources for the Characterization of Indoor Photovoltaic Applications", Energies, 2014, Vol. (7), pp. 1500-1516.

12. Ben Minnaert and Peter Veelaert, March 2014, "The Potential of Tandem Photovoltaic Solar Cells for Indoor Applications", 1st International e-Conference on Energies, pp. 14-31.

13. Georgia Apostolou, AngèleReinders and Martin Verwaa, "Comparison of the indoor performance of 12 commercial PV products by a simple model", Energy Science and Engineering, 2016, Vol. (4), No. (1), pp. 69-85.

14. W.A. Farooq, M. Atif, A. Fatehmulla, F. Yakuphanoglu and I.S. Yahia, "Impedance spectroscopy and transport mechanisms of $\mathrm{TiO}_{2}$-based dye sensitized solar cell", Journal of Ovonic Research, May - June 2014, Vol. (10), No. (3), pp. $61-66$.

15. DavudMostafaTobnaghi, MosaddeghSojoudi and Rahim Madatov, "Influence of Illumination Intensity on Electrical Parameters of Solar Cells", Technical Journal of Engineering and Applied Sciences, 2013, pp. 3854-3857.

16. A.A. Katkar, N.N. Shinde and Dr. P.S. Patil, "Performance and evaluation of industrial solar cell w.r.t. temperature and humidity", Intr. Jour. of Research in Mechanical Engineering and Technology, 2011, Vol. (1), No. (1), pp. 69-73.

17. FirozKhan ,n, S.N. Singh, M. Husain, " Effect of illumination intensity on cell parameters of a silicon solar cell", Solar Energy Materials \& Solar Cells, 2010, Vol. (94), pp. 1473-1476.

18. N.H. Reich, W.G.J.H.M.vanSark, E.A.Alsema, R.W.Lof, R.E.I.Schropp, W.C.Sinke, W.C.Turkenburg "Crystalline silicon cell performance at low light intensities", Solar Energy Materials \& Solar Cells, 2009, Vol. (93), pp. 1471-1481. 
19. M. Chegaar, A. Hamzaoui, A. Namoda, P. Petit, M. Aillerie and A. Herguth,"Effect of illumination intensity on solar cells parameters", 2013, TerraGreen 13 International Conference 2013 Advancements in Renewable Energy and Clean Environment, Energy Procedia,Vol. (36), pp. 722 - 729.

20. Pyungho Choi, Hyojung Kim, DohyunBaek, and Byoungdeog Choi, "A Study on the electrical characteristic analysis of c-Si solar cell diodes", Journal of Semiconductor Technology and Science, March 2012, Vol. (12), No. (1).

21. John Harper, Xin-dong Wang, "I-V, C-V and AC impedance techniques and characterizations of photovoltaic cells", The $7^{\text {th }}$ National Conference on Functional Materials and Applications.

22. S. R. Dhariwal, S. Mittal, R. K. Mathur, 1984, "Theory for voltage dependent series resistance in silicon solar cells", Solid-State Electronics, Vol. (27), pp. 267-273.

23. S. Demirezen, Z. Sönmez, U. Aydemir, S. Altındal, 2011, "Effect of series resistance and interface states on the I-V, C-V and G/ $\omega$-V characteristics in Au/Bidoped polyvinyl alcohol (PVA)/n-Si Schottky barrier diodes at room temperature", Current Applied Physics, pp.1-7,.

24. S.M. El-Ghanam, W. Abdel Basit, "Performance of electronic switching circuits based on bipolar power transistors at low temperature", Journal of Cryogenics, Elsevier Ltd., 2011, 51, pp. 117-123.

25. DavudMostafaTobnaghi, rahimMadatov and Daryushnaderi, "The Effect of Temperature on Electrical Parameters of Solar Cells", International journal of Advanced Research in Electrical, Electronics and Instrumentation Engineering, December 2013, Vol. (2), Issue (12), pp. 6404-6407.

26. SubhashChander and et. al., 2015, "A study on photovoltaic parameters of mono-crystalline silicon solar cell with cell temperature", Science Direct, El-Sevier, Energy Reports 1, pp. 104-109.

27. L. Arivuselvam, D. Sakthi, P. Sakthivel, P. M. Anbarasan and V. Aroulmoji, "Irradiance Dependence on Performance of Dye Sensitized and V-Grooved Silicon Solar Cells", Int. J. Adv. Sci. Eng., 2015, Vol. (1), No. (3), pp. 18-26.

28. PradhanArjyadhara, Ali S.M, Jena Chitralekha, "Analysis of Solar PV cell Performance with Changing Irradiance and Temperature", International Journal of Engineering and Computer Science, Jan 2013, Vol. (2), Issue (1), pp. 214-220,

29. Keerthi K Nair, Jitty Jose, AjithRavindran, "Analysis of temperature dependent parameters on solar cell efficiency using MATLAB", International Journal of Engineering Development and Research, 2016, Vol.(4), Issue (3), pp. 536-541,.

30. Lochan Jolly and Rutvi R. Panchal, 2013, "Implementation of one diode model solar cell capacitance to measure temperature", International Journal of Computer Applications, International Conference and Workshop on Emerging Trends in Technology, pp. 24-29.

\section{Authors}

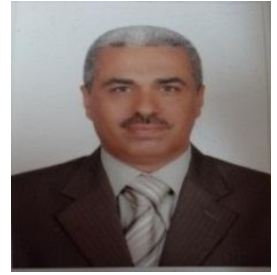

Ashraf Mosleh Abd El-Maksood, Lecturer of Electronics Engineering, Electronics Eng. Dept., Nuclear Materials Authority of Egypt. Major field of interest: Energy, Electronics, Radiation detection and computer programming and simulation.

Email:ashrafmosleh11@gmail.com 


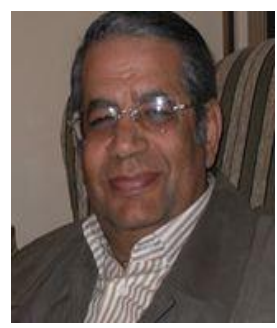

Fouad A. S. Soliman, Professor of Electronics and computers Eng., Nuclear Materials Authority of Egypt. Member of American Assoc. for Adv. of Sci's., N.Y., U.S.A and New York Academy of Sciences, New York, U.S.A.Editorial Board Member of: Progress in Photovoltaics "Research and Applications', John Wiley and Sons, UK, Periodicals of the Assoc. for Adv. of Modeling and Simulation Tech's., AMSE, Lune, France, Intr. Journal of Computer Sci. and Eng. Applications (IJCSEA). Chosen For: Who's Who in the World, A.N. Marquis, N.J., USA, and Outstanding People of the 20th Century, Intr. Biographical Center of Cambridge, England. Published three Books at Lambert Academic Publi-shing, LAP, Saarbrücken, Germany, ISBN 978-3-659-83496-7, ISBN 978-3-65988129-9, and "ISBN 978-3-659-89387-2

Email: fouad.saad.soliman@gmail.com 